\title{
Alterations of p53 and Rb Pathways Are Associated with High Proliferation in Bladder Urothelial Carcinomas
}

\author{
ANNA C. GOUSSIA ${ }^{1}$, ALEXANDRA PAPOUDOU-BAI ${ }^{1}$, ANTONIA CHARCHANTI ${ }^{2}$, PANAGIOTIS KITSOULIS ${ }^{2}$, \\ PANAGIOTIS KANAVAROS ${ }^{2}$, JOHN KALEF-EZRA ${ }^{3}$, DIMITRIOS STEFANOU ${ }^{1}$ and NIKI J. AGNANTIS ${ }^{1}$ \\ Departments of ${ }^{1}$ Pathology, ${ }^{2}$ Anatomy-Histology-Embryology and ${ }^{3}$ Medical Physics Medicine, \\ Medical Faculty, School of Health Sciences, University of Ioannina, Ioannina, Greece
}

\begin{abstract}
Background/Aim: Since most cancers are associated with alterations of the p53 and Rb pathways, the expression of p53,p21, Rb, p16, p27, cyclin D1, cyclin A, cyclin B1 and Ki67 proteins were analyzed in bladder urothelial carcinomas (BUC). Materials and Methods: One hundred twenty-two cases of BUC were studied by immunohistochemistry. Results: The pathways p53/p21 and Rb/p16/cyclin D1 exhibited alterations in $81 / 115$ and $63 / 84$ cases, respectively. Alterations of the p53/p21 and Rb/p16/cyclin D1 pathways were positively correlated with high cyclin A expression. High expression of p53, Ki67, cyclin $A$ and cyclin $B 1$ was inversely correlated with the papillary morphology of the tumor and positively with tumor grade and T-stage. Conclusion: The results showed that a) alterations of the p53 and $R b$ pathways are associated with high proliferation of tumor cells in BUC and b) high expression of cell-cycle proteins is associated with adverse histopathological parameters of these tumors.
\end{abstract}

Cell-cycle progression is regulated by a complex molecular network involving cyclins, cyclin-dependent kinases (CDK) and CDK inhibitors (CDKIs) (1). The p53 and Rb growth suppressor pathways play important roles in the regulation of the cell cycle (1). P53-dependent $\mathrm{G}_{1}-\mathrm{S}$ and $\mathrm{G}_{2}-\mathrm{M}$ cell-cycle arrest is mediated, at least in part, through p53-mediated induction of the CDKI p21 and by repression of the promoters of cyclin B1 and CDK1, respectively (1). The Rb pathway is involved in the inhibition of transcription of genes necessary for the $\mathrm{G}_{1}-\mathrm{S}$ transition (1). Hypophosphorylated $\mathrm{Rb}$ protein $(\mathrm{pRb})$ binds and inactivates transcription factors,

Correspondence to: Anna Goussia, MD, Ph.D., Department of Pathology, Medical Faculty, School of Health Sciences, University of Ioannina, University Campus, 45110 Ioannina, Greece. Tel: +30 2651099413,e-mail: agoussia@uoi.gr

Key Words: Bladder carcinomas, cell cycle, p53, Rb, proliferation, immunohistochemistry. notably the E2F1, important for the $G_{1}-S$ transition. As the cycle proceeds, $\mathrm{pRb}$ becomes hyperphosphorylated and looses its ability to bind to E2F1. The phosphorylation of $\mathrm{pRb}$ is achieved by the cyclin D-CDK4/6 complexes and inhibited by the CDKI p16 (1).

Abnormalities of cell-cycle components are common in bladder urothelial carcinomas (BUC) and may be relevant with respect to the pathogenetic and clinical behaviour of these tumors (2-37). For example, p53 mutations and/or protein overexpression were significantly related with tumor grade, stage and the presence of lymph node metastases (2, 4). p21 protein expression was an independent predictor of tumor progression (11). Moreover, patients with low p21 expression had shorter recurrence-free survival and overall survival rates (30). Interestingly, patients with $\mathrm{p} 53+/ \mathrm{p} 21-$ tumors had a higher rate of recurrence and worse survival than those with $\mathrm{p} 53+/ \mathrm{p} 21+$ tumors (7). Altered $\mathrm{pRb}$ protein expression occurs in all grades and stages of BUC but was more commonly noticed in higher grade and muscle invasive tumors (3). The immunohistochemical overexpression of $\mathrm{pRb}$ protein has been associated with increased rate of progression and decreased survival (6). Abnormal expression of the p16 and cyclin D1 proteins has been involved in urothelial tumorigenesis and tumor recurrence $(12,15,18)$. Importantly, the results of a meta-analysis showed a link between downregulated p16 expression and poor prognosis in patients with BUC in terms of recurrence-free survival (RFS), overall survival (OS), progression-free survival (PFS), and some clinicopathological parameters including clinical staging, pathological grade and lymph node metastasis (31). Reduced expression of p27 protein has been associated with aggressive and highly proliferating BUC, as well as with unfavorable prognosis $(9,13)$.

Interestingly, concomitant alterations of various cell-cycle regulators have been associated with tumor recurrence and aggressive behavior of $\operatorname{BUC}(5,19,24,37)$, but the impact of such concurrent alterations on tumor cell proliferation, to the best of our knowledge, has not been analyzed so far. Thus, the expression of p53, p21, pRb, p16, p27, cyclin D1, 
cyclin A, cyclin B1 and Ki67 proteins in 122 cases of BUC were investigated in order: a) to search for immunohistochemical alterations of these cell cycle regulatory proteins, b) to determine the proliferation status (expression of cyclin A, cyclin B1, Ki67), c) to analyze the impact of concurrent immunohistochemical alterations of p53 and $\mathrm{Rb}$ growth suppressor pathways on tumor cell proliferation and d) to correlate the findings with histopathological parameters.

\section{Materials and Methods}

Tissue samples. A total of one hundred twenty-two (122) cases of BUC was selected from the files of the Department of Pathology, University Hospital of Ioannina on the basis that fixed tissue was available for performing multiparametric immunohistochemical analysis. Cases were assigned into two grade categories (low and high) and in each case the tumor configuration (papillary/ nonpapillary) and the pathological stage (pT) were recorded.

Immunohistochemistry. Immunohistochemical analyses were performed on paraffin-embedded tissue sections by the labelled streptavidin avidin biotin method (LSAB kit, Dako SA, Glostrup, Denmark). Pretreatment of the sections with $10 \mathrm{mM}$ sodium citrate buffer ( $\mathrm{pH}$ 6.0) in a microwave oven was performed. Monoclonal antibodies directed against p53 protein (DO-7; Dako SA; dilution 1:50), p21 (NCL-WAF-1; Novocastra, Newcastle upon Tyne, UK, dilution 1:20), pRb (Ab-5; Oncogene, CA, USA; dilution 1:50), p16 (F-12; Santa Cruz Biotechnology, Texas, USA; dilution 1:50;), p27 (IB4; Novocastra; dilution 1:50), cyclin D1 (DCS-6; Novocastra; dilution 1:50), cyclin A (6E6; Novocastra; dilution 1:50), cyclin B1 (7A9; Novocastra; dilution 1:10) and Ki67 (MIB1; Dako SA; dilution 1:50) were applied. Positive control slides were included and consisted of thymus and non-Hodgkin lymphomas from our previous studies $(38,39)$. Negative controls consisted in the same immunohistochemical method with omission of the primary antibody. A continuous score system was adopted and the number of immunopositive cells was divided by the total number of the counted cells and the expression was defined as the percentage of positive cells in the total number of the counted cells. p53, p21, Rb, p16, cyclin D1 and p27 aberrant expression patterns were determined on the basis of previous published criteria $(20,22,24)$.

Statistical analysis. The program SPSS for Windows Release 10 was used and the results were considered as statistically significant when $p<0.05$.

\section{Results}

Expression of p53, p21, pRb, p16, p27, cyclin D1, cyclin A, cyclin B1 and Ki67 proteins and correlations with histopathological parameters. The non-neoplastic urothelium expressed Ki67, cyclin A, cyclin B1, pRb, p16, p21 and p27 proteins but was negative for p53 and cyclin D1.

High expression ( $>10 \%$ of neoplastic cells) levels of the proteins p53, p21, pRb, p16, p27, cyclin D1, cyclin A, cyclin
B1 and Ki67 were found in 79/122 (64.75\%), 20/121 (16.53\%), 51/115 (44.35\%), 74/95 (77.9\%), 80/88 (90.9\%), $39 / 120$ (32.5\%), 38/113 (33.63\%), 6/97 (6.18\%), 57/101 $(56.43 \%)$ of the cases, respectively.

Using the Spearman's correlation coefficient test, significant positive correlations were found between $\mathrm{p} 53 / \mathrm{p} 21$ $(p=0.001), \mathrm{p} 53 /$ cyclin A $(p<0.001), \mathrm{p} 53 / \mathrm{Ki} 67 \quad(p=0.005)$, $\mathrm{p} 21 /$ cyclin D1 $(p<0.001), \mathrm{p} 21 /$ cyclin A $\quad(p=0.006)$, $\mathrm{pRb} /$ cyclin A $(p=0.003), \mathrm{pRb} /$ cyclin B1 $(p=0.031)$ and cyclin D1/cyclin A $(p=0.048)$.

High expression ( $>10 \%$ of neoplastic cells) levels of p53, cyclin A, cyclin B1 and Ki67 proteins were inversely correlated with the papillary morphology of the tumor ( $p=0.026, p<0.0001, p<0.0001$, and $p=0.001$, respectively) and positively with tumor grade $(p=0.014, p<0.0001$, $p=0.002$, and $p=0.027$, respectively) and pT-stage $(p=0.014$, $p<0.0001, p=0.004$, and $p=0.025$, respectively).

Alterations of the p53/p21 and Rb/p16/cyclin D1 growth suppressor pathways. The normal and aberrant p53/p21 and $\mathrm{Rb} / \mathrm{p} 16 /$ cyclin D1 patterns are shown in Tables I and II. Totally, aberrant p53/p21 patterns were observed in $81 / 115$ $(70.43 \%)$ cases and aberrant $\mathrm{Rb} / \mathrm{p} 16 /$ cyclin D1 patterns were observed in $63 / 84(75 \%)$ cases. Concomitant alterations of $\mathrm{p} 53 / \mathrm{p} 21-\mathrm{Rb} / \mathrm{p} 16 /$ cyclin D1 pathways were found in $40 / 77$ $(51.95 \%)$ of cases.

Correlations of the combined alterations of the p53 and $R b$ growth suppressor pathways with proliferation profile and histopathological parameters. The combined expression patterns of p53/p21 and Rb/p16/cyclin D1 were analyzed with respect to the expression of cyclin A, cyclin B1 and Ki67 proteins. Using analysis of variance, the aberrant p53/p21 phenotypes were positively correlated with cyclin A expression $(p=0.002)$ and the aberrant Rb/p16/cyclin D1 phenotypes were positively correlated with cyclin A expression $(p=0.04)$.

\section{Discussion}

In the present study, high expression $(>10 \%$ of neoplastic cells) levels of p53, cyclin A, cyclin B1 and Ki67 proteins were inversely correlated with the papillary morphology of the tumor and positively correlated with tumor grade and pTstage. These results are in keeping with previous studies (25, $32,37)$ and show that high expression of cell cycle proteins such as p53, cyclin A, cyclin B1 and Ki67 is associated with adverse histopathological parameters.

In our study, immunohistochemical alterations of the $\mathrm{p} 53 / \mathrm{p} 21$ and $\mathrm{Rb} / \mathrm{p} 16 /$ cyclin D1 pathways were found in $81 / 115(70.43 \%)$ and $63 / 84(75 \%)$ of the cases, respectively. These findings are in keeping with previous immunohistochemical data $(10,24)$ and indicate that a large number 
Table I. p53/p21 expression patterns.

\begin{tabular}{lcc}
\hline Patterns & Number of cases & \\
\hline p53+/p21+ & $16 / 115(13.91 \%)$ & Aberrant \\
p53+/p21- & $61 / 115(53.04 \%)$ & Aberrant \\
p53-/p21- & $4 / 115(3.48 \%)$ & Aberrant \\
p53-/p21+ & $34 / 115(29.56 \%)$ & Normal \\
Total cases & $81 / 115(70.43 \%)$ & Aberrant/total \\
\hline
\end{tabular}

Cut-off of positivity: the expression of the proteins in at least $10 \%$ of neoplastic cells was considered positive expression.

Table II. Rb/p16/cyclin D1 expression patterns.

\begin{tabular}{lcc}
\hline Patterns & Number of cases & \\
\hline $\mathrm{Rb}+/ \mathrm{p} 16+/$ cyclin D1- & $21 / 84(25 \%)$ & Normal \\
$\mathrm{Rb}+/ \mathrm{p} 16-/$ cyclin D1- & $3 / 84(3.57 \%)$ & Aberrant \\
$\mathrm{Rb}-/ \mathrm{p} 16+/$ cyclin D1- & $23 / 84(27.39 \%)$ & Aberrant \\
$\mathrm{Rb}-/ \mathrm{p} 16-/$ cyclin D1- & $9 / 84(10.71 \%)$ & Aberrant \\
$\mathrm{Rb}+/ \mathrm{p} 16+/$ cyclin D1+ & $8 / 84(9.52 \%)$ & Aberrant \\
$\mathrm{Rb}+/ \mathrm{p} 16-/$ cyclin D1+ & $6 / 84(7.14 \%)$ & Aberrant \\
$\mathrm{Rb}-/ \mathrm{p} 16+/$ cyclin D1+ & $13 / 84(15.48 \%)$ & Aberrant \\
$\mathrm{Rb}-/ \mathrm{p} 16-/$ cyclin D1+ & $1 / 84(1.19)$ & Aberrant \\
Total & $63 / 84(75 \%)$ & Aberrant/total \\
\hline
\end{tabular}

Cut-off of positivity: the expression of the proteins in at least $10 \%$ of neoplastic cells was considered positive expression.

of BUC display alterations of at least one of the growth suppressor pathways. Furthermore, concomitant alterations of p53/p21-Rb/p16/cyclin D1 pathways in 40/77 (51.95\%) of the cases were observed. These findings indicate that concurrent alterations of the $\mathrm{p} 53 / \mathrm{p} 21$ and $\mathrm{Rb} / \mathrm{p} 16 /$ cyclin $\mathrm{D} 1$ pathways are frequent in BUC and may play important roles in their biological behavior. Indeed, alterations in both p53 and $\mathrm{Rb}$ may act cooperatively to promote bladder cancer progression $(5,6,19)$. The novel finding of the present study is that the alterations in the $\mathrm{p} 53 / \mathrm{p} 21$ and $\mathrm{Rb} / \mathrm{p} 16 /$ cyclin $\mathrm{D} 1$ expression status were significantly associated with high expression levels of cyclin A. The above data suggest that the impairment of $\mathrm{p} 53$ and $\mathrm{Rb}$ pathways in BUC results in enhanced tumor cell proliferation.

In conclusion, our results show that a) alterations of the p53 and $\mathrm{Rb}$ pathways are common and associated with high proliferation of tumor cells in BUC and b) high expression of cell cycle proteins such as p53, cyclin A, cyclin B1 and Ki67 is associated with adverse histopathological parameters of these tumors.

\section{References}

1 Malumbres $\mathrm{M}$ and Barbacid M: To cycle or not to cycle: a critical decision in cancer. Nat Rev Cancer 1: 222-231, 2001.

2 Soini Y, Turpeenniemi-Hujanen T, Kamel D, Autio-Harmainen H, Risteli J, Nuorva K, Paakko P and Vahakangas K: p53 immunohistochemistry in transitional cell carcinoma and dysplasia in urinary bladder correlates with disease progression. Br J Cancer 68: 1029-1035, 1993.

3 Xu HJ, Cairns P, Hu SX, Li J, Knowles MA and Benedict WF: Loss of $\mathrm{Rb}$ protein expression in primary bladder cancer correlates with loss of heterozygosity at the Rb locus and tumour progression. Int J Cancer 53: 781-784, 1993.

4 Matsuyama H, Pan Y, Mahdy EA, Malmstrom PU, Hedrum A, Uhlen M, Busch C, Hirano C, Auer G, Tribukait B, Naito K, Lichter P, Ekman P and Bergerheim USR: p53 deletion as a genetic marker in urothelial tumor by fluorescence in situ hybridization. Cancer Res 54: 6057-6060, 1994.

5 Cordon-Cardo C, Zhang ZF, Dalbagni G, Drobnjak M, Charytonowicz E, Hu SX, Xu HJ, Reuter VE and Benedict WF: Cooperative effects of $\mathrm{p} 53$ and $\mathrm{Rb}$ alterations in primary superficial bladder tumours. Cancer Res 57: 1217-1221, 1997.

6 Cote RJ, Dunn MD, Chatterjee SJ, Stein JP, Shi SR, Tran QC, Hu SX, Xu HJ, Groshen S, Taylor CR, Skinner DG and Benedict WF: Elevated and absent $\mathrm{pRb}$ expression is associated with bladder cancer progression and has cooperative effects with p53. Cancer Res 58: 1090-1094, 1998.

7 Stein JP, Ginsberg DA, Grossfeld GD, Chatterjee SJ, Esring D, Dickinson MG, Groshen S, Taylor CR, Jones PA, Skinner DG and Cote RJ: Effect of p21 WAF1/CIP1 expression on tumor progression in bladder cancer. Natl Cancer 90: 1072-1079, 1998.

8 Stavropoulos NE, Ioachim E, Hastazeris K, Goussia A and Agnantis NJ: Lymphocytic subsets in superficial bladder cancer: correlation with the biological activity of the tumours. Anticancer Res 18: 2037-2040, 1998.

9 Sgambato A, Migaldi M, Faraglia B, Garagnani L, Romano G, De Gaetani C, Ferrari P, Capelli G, Trentini GP and Cittadini A: Loss of P27Kip1 expression correlates with tumor grade and with reduced disease-free survival in primary superficial bladder cancers. Cancer Res 59: 3245-3250, 1999.

10 Niehans GA, Kratzke RA, Froberg MK, Aeppli DM, Nguyen PL and Geradts J: G1 checkpoint protein and p53 abnormalities occur in most invasive transitional cell carcinomas of the urinary bladder. Br J Cancer 80: 1175-1184, 1999.

11 Migaldi M, Sgabato A, Garagnani L, Ardito R, Ferrari P, De Gaetani C, Cittadini A and Trentini GP: Loss of p21waf1 expression is a strong predictor of reduced survival in primary superficial bladder cancers. Clin Cancer Res 6: 3131-3138, 2000.

12 Liukkonen T, Lipponen P, Raitanen M, Kaasiner E, Ala-Opas M, Rajala P and Kosma VM: Evaluation of $\mathrm{p} 21^{\mathrm{WAF} 1 / \mathrm{CIP} 1}$ and cyclin D1 expression in the progression of superficial bladder cancer. Urol Res 28: 285-292, 2000.

13 Korkolopoulou P, Christodoulou P, Konstantinidou AE, ThomasTsagli E, Kapralos P and Davaris P: Cell cycle regulators in bladder cancer: A multivariate survival study with emphasis on p27Kip1. Hum Pathol 31: 751-760, 2000.

14 Ioachim E, Charchanti A, Stavropoulos NE, Skopelitou A, Athanassiou ED and Agnantis NJ: Immunohistochemical expression of retinoblastoma gene product $(\mathrm{Rb}), \mathrm{p} 53$ protein, 
MDM2, c-erbB-2, HLA-DR and proliferation indices in human urinary bladder carcinoma. Histol Histopathol 15: 721-727, 2000.

15 Sgambato A, Migaldi M, Faraglia B, De Aloysio G, Ferrari P, Ardito R, De Gaetani C, Capelli G, Cittadini A and Trentini GP: Cyclin D1 expression in papillary superficial bladder cancer: its association with other cell-cycle associated proteins, cell proliferation and clinical outcome. Int J Cancer 97: 671-678, 2002.

16 Primdahl H, von der Maase H, Sørensen FB, Wolf H and Ørntoft TF: Immunohistochemical study of expression of cell cycle regulating proteins at different stages of bladder cancer. J Cancer Res Clin Oncol 128: 295-301, 2002.

17 Ioachim E, Charchanti A, Stavropoulos N, Athanassiou E, Bafa $\mathrm{M}$ and Agnantis NJ: Expression of cathepsin D in urothelial carcinoma of the urinary bladder: an immunohistochemical study including correlations with extracellular matrix components, $\mathrm{CD} 44, \mathrm{p} 53, \mathrm{Rb}, \mathrm{c}-\mathrm{erbB} 2$ and the proliferation indices. Anticancer Res 22: 3383-3388, 2002.

18 Tsai TS, Tsai YS and Chow NH: The prevalence and clinicopathologic correlate of p16 $6^{\mathrm{INK} 4 \mathrm{a}}$, retinoblastoma and $\mathrm{p} 53$ immunoreactivity in locally advanced urinary bladder cancer. Urol Oncol 22: 112-118, 2004.

19 Chatterjee SL, Datar R, Youssefradeh D, George B, Goebell PJ, Stein JP, Young L, Shi SR, Gee C, Groshen S, Skinner DG and Cote RJ: Combined effects of p53, p21, and pRb expression in the progression of bladder transitional cell carcinoma. J Clin Oncol 22: 1007-1013, 2004.

20 Krüger S, Mahnken A, Kausch I and Feller AC: P16 immunoreactivity is an independent predictor of tumor progression in minimally invasive urothelial bladder carcinoma. Eur Urol 47: 463-467, 2005.

21 Krüger S, Lange I, Kausch I and Feller AC: Protein expression and gene copy number analysis of topoisomerase 2alpha, HER2 and P53 in minimally invasive urothelial carcinoma of the urinary bladder - a multitissue array study with prognostic implications. Anticancer Res 25: 263-271, 2005.

22 Shariat SF, Ashfaq R, Sagalowsky AI and Lotan Y: Correlation of cyclin D1 and E1 expression with bladder cancer presence, invasion, progression, and metastasis. Hum Pathol 37: 15681576, 2006.

23 Kawamoto K, Enokida H, Gotanda T, Kubo H, Nishiyama K, Kawahara $M$ and Nakagawa $M$ : P16 INK4 $\alpha$ and p14ARF methylation as a potential biomarker for human bladder cancer. Bioch Biophys Res Commun 339: 790-796, 2006.

24 Shariat SF, Zlotta AR, Ashfaq R, Sagalowsky AI and Lotan Y: Cooperative effect of cell-cycle regulators expression on bladder cancer development and biologic aggressiveness. Mod Pathol 20: 445-459, 2007.

25 Brunner A, Verdorfer I, Prelog M, Mayerl C, Mikuz G and Tzankov A: Large-scale analysis of cell cycle regulators in urothelial bladder cancer identifies p16 and p27 as potentially useful prognostic markers. Pathobiology 75: 25-33, 2008.

26 Rosenblatt R, Jonmarker S, Lewensohn R, Egevad L, Sherif A, Kalkner KM, Nilsson S, Valdman A and Ullen A: Current status of prognostic immunohistochemical markers for urothelial bladder cancer. Tumour Biol 29: 311-322, 2008.

27 Castillo-Martin M, Domingo-Domenech J, Karni-Schmidt O, Matos T and Cordon-Cardo C: Molecular pathways of urothelial development and bladder tumorigenesis. Urol Oncol 28: 401408, 2010.
28 Aaltonen V and Peltonen J: PKCalpha/beta I inhibitor Go6976 induces dephosphorylation of constitutively hyperphosphorylated $\mathrm{Rb}$ and G1 arrest in T24 cells. Anticancer Res 30: 3995-3999, 2010.

29 Lotan Y, Bagrodia A, Passoni N, Rachakonda V, Kapur P, Arriaga Y, Bolenz C, Margulis V, Raj GV, Sagalowsky A and Shariat SF: Prospective evaluation of a molecular marker panel for prediction of recurrence and cancer-specific survival after radical cystectomy. Eur Urol 64: 465-471, 2013.

30 Tang K, Wang C, Chen Z, Xu H and Ye Z: Clinicopathologic and prognostic significance of p21 (Cip1/Waf1) expression in bladder cancer. Int J Clin Exp Pathol 8: 4999-5007, 2015.

31 Gan X, Lin X, He R, Lin X, Wang H, Yan L, Zhou H, Qin H and Chen G: Prognostic and Clinicopathological Significance of Downregulated p16 Expression in Patients with Bladder Cancer: A Systematic Review and Meta-Analysis. Dis Markers 2016: 5259602, 2016.

32 Tian Y, Ma Z, Chen Z, Li M, Wu Z, Hong M, Wang H, Svatek R, Rodriguez R and Wang Z: Clinicopathological and Prognostic Value of Ki-67 Expression in Bladder Cancer: A Systematic Review and Meta-Analysis. PLoS One 11: e015889, 2016.

33 Kiselyov A, Bunimovich-Mendrazitsky S and Startsev V: Key signaling pathways in the muscle-invasive bladder carcinoma: Clinical markers for disease modeling and optimized treatment. Int J Cancer 138: 2562-2569, 2016.

34 Ning $\mathrm{X}$ and Deng Y: Identification of key pathways and genes influencing prognosis in bladder urothelial carcinoma. Onco Targets Ther 10: 1673-168, 2017.

35 Hussain SA, Palmer DH, Syn WK, Sacco JJ, Greensmith RM, Elmetwali T, Aachi V, Lloyd BH, Jithesh PV, Arrand J, Barton D, Ansari J, Sibson DR and James ND: Gene expression profiling in bladder cancer identifies potential therapeutic targets. Int J Oncol 50: 1147-1159, 2017.

36 Zheng L, Zhu Y, Lei L, Sun W, Cheng G and Yang S: Significant expression of CHK1 and p53 in bladder urothelial carcinoma as potential therapeutic targets and prognosis. Oncol Lett 15: 568574, 2018.

37 da Silva JNL, Ranzi AD, Carvalho CT, Scheide TV, Strey YTM, Graziottin TM and Bica CG: Cell cycle markers in the evaluation of bladder cancer. Pathol Oncol Res, 2018. doi: 10.1007/s12253-018-0389-5. [Epub ahead of print]

38 Kanavaros P, Stefanaki K, Rontogianni D, Papalazarou D, Sqantzos M, Arvanitis D, Vamvouka C, Gorgoulis V, Siatitsas I, Agnantis NJ and Bai M: Immunohistochemical expression of p53, p21/Walf, Rb, p16, cyclin D1, p27, Ki67, cyclin A, cyclinB1, bcl2, bax and bak proteins and apoptotic index in normal thymus. Histol Histopathol 16: 1005-1012, 2001.

39 Bai M, Vlachonikolis J, Agnantis NJ, Tsanou E, Dimou S, Nicolaides C, Stefanaki S, Pavlidis N and Kanavaros P: Low expression of p27 protein combined with altered p53 and Rb/p16 expression status is associated with increased expression of cyclin A and cyclin B1 in Diffuse Large B-cell Lymphomas. Mod Pathol 14: 1105-1113, 2001.

Received April 26, 2018

Revised May 29, 2018

Accepted May 30, 2018 